\title{
Dietary modulation of the expression of genes involved in short-chain fatty acid absorption in the rumen epithelium is related to short-chain fatty acid concentration and $\mathrm{pH}$ in the rumen of goats
}

\author{
Lei Yan, Bei Zhang, and Zanming Shen ${ }^{1}$ \\ Laboratory of Animal Physiology and Biochemistry, Nanjing Agriculture University, 210095 Nanjing, China
}

\begin{abstract}
We have tested the hypothesis that increased concentrate intake induces mRNA abundance alterations of genes involved in short-chain fatty acid (SCFA) absorption in the rumen epithelium of goats and these changes of mRNA abundance are probably related to ruminal SCFA concentration and ruminal $\mathrm{pH}$. Goats $(\mathrm{n}=12)$ were randomly allocated to 2 groups and fed either a low-concentrate (LC) diet (10\% concentrate; $\mathrm{n}=6)$ or a medium-concentrate (MC) diet (35\% concentrate; $\mathrm{n}=6$ ) in 2 equal portions daily. Goats were fed separately with their respective diet for $3 \mathrm{wk}$. The goats were slaughtered $6 \mathrm{~h}$ after the morning feeding on $\mathrm{d} 22$. In vivo, goats in the MC treatment exhibited a greater ruminal SCFA concentration $(81.9 \mathrm{mM})$ compared with those in the LC treatment $(58.0 \mathrm{mM})$, and the $\mathrm{pH}$ decreased from 7.03 to 6.63. Correspondingly, mRNA expression of candidates for $\mathrm{SCFA}^{-} /$ $\mathrm{HCO}_{3}{ }^{-}$exchangers, namely downregulated in adenoma $(D R A)$, putative anion transporter 1 (PAT1), and anion exchanger 2 (AE2) were increased in the MC group. Further, upregulation in monocarboxylate transporter 1 (MCT1) and monocarboxylate transporter 4 (MCT4) mRNA abundances was observed in the MC group. The expression of genes that help the rumen epithelial cells to maintain intracellular $\mathrm{pH}$, including $\mathrm{Na}^{+} / \mathrm{H}^{+}$exchanger 1 (NHE1) , NHE2, NHE3, vacuolar $\mathrm{H}^{+}$ATPase subunit B ( $v H^{+}$ATPase $)$, and $\mathrm{Na}^{+} / \mathrm{K}^{+}$ATPase pump subunit $\alpha 1\left(\mathrm{Na}^{+} / \mathrm{K}^{+}\right.$ATPase $)$were also enhanced in the MC group relative to the LC group. During in vitro studies with isolated rumen epithelial cells from goats, exposure to a $\mathrm{pH}$ of 6.8 increased MCT1 mRNA expression after $24 \mathrm{~h}$ of culture, whereas the mRNA expression of AE2 was downregulated. The presence of SCFA $(20 \mathrm{mM})$ in the medium increased DRA, PAT1, AE2, $M C T 1$, and $\mathrm{Na}^{+} / \mathrm{K}^{+}$ATPase mRNA expression. The expression of $v H^{+}$ATPase was decreased by increased SCFA concentration. The mRNA expression of MCT4
\end{abstract}

Received December 5, 2013.

Accepted May 7, 2014.

${ }^{1}$ Corresponding author: zmshen@njau.edu.cn did not vary in vitro with $\mathrm{pH}(6.8)$ or SCFA $(20 \mathrm{mM})$. The expression of $D R A$ was increased by synergistic effects of higher SCFA concentration and lower $\mathrm{pH}$, similar to that of MCT1. Thus, diet-dependent rumen epithelial mRNA expression changes in genes involved in SCFA absorption are probably related to ruminal SCFA concentration and $\mathrm{pH}$.

Key words: rumen epithelium, gene expression, short-chain fatty acid absorption, short-chain fatty acid and $\mathrm{pH}$

\section{INTRODUCTION}

Ruminal short-chain FA (SCFA) can be efficiently absorbed by the rumen epithelium via diffusion or a protein-mediated pathway (Leonhard-Marek et al., 2010; Aschenbach et al., 2011). Past research has demonstrated that feeding a high-concentrate diet could lead to enhanced SCFA absorptive capacity of rumen epithelium (Gäbel et al., 1991), even when no change occurred in the absorptive surface area of the rumen papillae (Sehested et al., 2000). Some experiments show that one reason for the changes of SCFA absorptive capacity is that diets could modulate the expression of genes encoding for proteins involved in SCFA absorption (Connor et al., 2010; Kuzinski and Röntgen, 2011).

The luminal factors, especially SCFA and $\mathrm{pH}$, have been proven to contribute to the alterations in $\mathrm{Na}^{+} /$ $\mathrm{H}^{+}$exchanger 1 (NHE1) and NHE3 expression in the rumen epithelium induced by diets (Yang et al., 2012). Furthermore, Metzler-Zebeli et al. (2013) found that the expression of monocarboxylate transporter 1 ( MCT1) and $\mathrm{Na}^{+} / \mathrm{K}^{+}$ATPase pump subunit $\alpha 1\left(\mathrm{Na}^{+} /\right.$ $K^{+}$ATPase) in the rumen epithelium of goats were strongly tied to ruminal $\mathrm{pH}$ values by using regression analyses. Despite the underlying mechanisms not being completely clear, these experiments, together with previous studies in vitro (Fejes-Tóth et al., 1998; Cuff et al., 2002), showed that SCFA and $\mathrm{pH}$ could affect the mRNA expression of SCFA transporters. However, the majority of previous studies were conducted using other animals or tissues, such as rabbit cortical collecting duct and human colonic epithelium; therefore, more 
investigation is necessary in the rumen epithelium of goats.

We hypothesized that feeding more concentrate would upregulate the expression of genes involved in the SCFA absorption and that dietary effects on the expression of genes were associated with ruminal SCFA and $\mathrm{pH}$. The current experiments therefore focused on in vivo effects of diet [low concentrate (LC; $10 \%$ concentrate) vs. medium concentrate (MC; $35 \%$ concentrate)] and in vitro effects of SCFA concentration and $\mathrm{pH}$ value (acidified by $\mathrm{HCl}$ ) on mRNA expression of genes related to SCFA absorption in rumen epithelial cells.

\section{MATERIALS AND METHODS}

The experimental design and procedures were approved by the Animal Care and Use Committee of Nanjing Agricultural University, following the requirements of the Regulations for the Administration of Affairs Concerning Experimental Animals.

\section{Experimental Design and Goat Management}

Twelve goats (Boer $\times$ Yangtze River Delta White), aged $4 \mathrm{mo}$ at the commencement of the experiment, were used for the feeding trial. The treatments contained concentrate at $10 \%(\mathrm{LC})$ and $35 \%(\mathrm{MC})$ of dietary DM. The composition of the MC and LC diets

Table 1. Composition of diets and DMI

\begin{tabular}{|c|c|c|}
\hline \multirow[b]{2}{*}{ Item } & \multicolumn{2}{|c|}{ Treatment $^{1}$} \\
\hline & $\mathrm{LC}$ & $\mathrm{MC}$ \\
\hline \multicolumn{3}{|l|}{ Ingredient ( $\%$ of DM) } \\
\hline Guinea grass & 90 & 65 \\
\hline Corn meal & 0 & 25 \\
\hline Soybean meal & 8 & 8 \\
\hline Mineral and vitamin supplement ${ }^{2}$ & 1 & 1 \\
\hline $\mathrm{NaCl}$ & 0.25 & 0.25 \\
\hline $\mathrm{CaHPO}_{4}$ & 0.75 & 0.75 \\
\hline \multicolumn{3}{|l|}{ Chemical composition } \\
\hline $\mathrm{DM}(\%)$ & 91.4 & 89.9 \\
\hline $\mathrm{CP}(\%$ of DM) & 10.3 & 10.7 \\
\hline Crude fat (\% of DM) & 3.5 & 3.4 \\
\hline Ash $(\%$ of DM) & 4.7 & 3.9 \\
\hline NDF (\% of DM) & 66.8 & 50.7 \\
\hline $\mathrm{NFC}^{3}(\%$ of DM $)$ & 14.7 & 31.3 \\
\hline $\mathrm{ME}(\mathrm{MJ} / \mathrm{kg}$ of DM) & 8.9 & 10.1 \\
\hline \multicolumn{3}{|l|}{ Intake } \\
\hline Total DMI (g/d) & $431.2 \pm 9.8$ & $487.4 \pm 6.5^{*}$ \\
\hline \multicolumn{3}{|c|}{$\begin{array}{l}{ }^{2} \mathrm{Contained} 16 \% \text { calcium carbonate, } 102 \mathrm{~g} \text { of } \mathrm{Zn} / \mathrm{kg}, 47 \mathrm{~g} \text { of } \mathrm{Mn} / \mathrm{kg} \text {, } \\
26 \mathrm{~g} \text { of } \mathrm{Cu} / \mathrm{kg}, 1,140 \mathrm{mg} \text { of } \mathrm{I} / \mathrm{kg}, 500 \mathrm{mg} \text { of } \mathrm{Se} / \mathrm{kg}, 340 \mathrm{mg} \text { of } \mathrm{Co} / \\
\mathrm{kg}, 17,167,380 \mathrm{IU} \text { of vitamin } \mathrm{A} / \mathrm{kg}, 858,370 \mathrm{IU} \text { of vitamin } \mathrm{D} / \mathrm{kg} \text {, and } \\
23,605 \mathrm{IU} \text { of vitamin } \mathrm{E} / \mathrm{kg} \text {. } \\
{ }^{3} \mathrm{NFC}=100-(\mathrm{NDF}+\mathrm{CP}+\text { crude fat }+ \text { ash }) . \\
{ }^{*} \text { Different from LC }(P<0.05) .\end{array}$} \\
\hline
\end{tabular}

is presented in Table 1. Replacing part (almost 30\%) of guinea grass with corn meal increased the dietary NFC concentration from 14.7 to $31.3 \%$, and decreased the dietary NDF concentration by almost $17 \%$. The concentration of $\mathrm{CP}$ was similar across treatments, averaging $10.5 \%$. Goats were placed in individual pens $(1.2 \times 1.0 \mathrm{~m})$ with free access to water. Goats were fed in 2 equal portions at 0800 and $1700 \mathrm{~h}$ daily, and the amounts of feed offered and refused by each goat was recorded daily throughout the experiment. The amount of feed supplied was adjusted to ensure approximately $25 \%$ orts. Adaptation to the diets was carried out over $10 \mathrm{~d}$, and goats received their respective treatment for at least $21 \mathrm{~d}$ before slaughter. All goats were slaughtered $6 \mathrm{~h}$ after feeding in the morning at a local slaughterhouse.

Feed was sampled at $\mathrm{d} 7$ and 21 for chemical analysis. The samples of the feed refusals were collected for DM determination on the same day. Dry matter, ash, CP, and crude fat contents were determined as in our previous work (Malhi et al., 2013). Concentration of NDF was determined using amylase and sodium sulfite (Van Soest et al., 1991).

\section{Sample Collection}

Immediately after slaughter, subsamples of ruminal fluid were collected in equal portions from the atrium ruminis, ventral rumen, caudal dorsal, and caudal ventral regions separately and then combined to form 1 sample. The ruminal fluid $(30 \mathrm{~mL})$ was strained through 3 layers of cheesecloth and immediately subjected to $\mathrm{pH}$ measurement. Thereafter, $5 \% \mathrm{HgCl}_{2}$ solution $(1.5 \mathrm{~mL})$ was added, and the sample was stored at $-20^{\circ} \mathrm{C}$. Rumen tissue from the ventral blind sac was quickly excised and loosely adherent feed particles were removed, placed in ice-cold PBS (pH 7.4), and repeatedly rinsed until the PBS remained clear. Epithelium for the cell culture was transported in ice-cold PBS to the laboratory. Epithelium for extracting RNA was separated from the muscle layers and transferred into liquid $\mathrm{N}$ within $5 \mathrm{~min}$ and stored at $-80^{\circ} \mathrm{C}$.

\section{Cell Culture}

Rumen epithelial cells were isolated from the rumen epithelium of 8 healthy goats (Boer $\times$ Yangtze River Delta White, aged 6-12 mo; both sexes) with $0.25 \%$ trypsin as described previously (Gálfi et al., 1981). Viability of the cells was confirmed by staining with trypan blue, and the cell density was adjusted to $\times 1,000,000$ cells $/ \mathrm{mL}$ in high-glucose $(4,500 \mathrm{mg} / \mathrm{L})$ Dulbecco's modified Eagle's medium (DMEM; Life Technologies Inc., Gibco/Brl Division, Grand Island, 
NY) with $10 \%$ fetal bovine serum (Zhejiang Tianhang Biological Technology Co. Ltd., Hangzhou, China), 2 $\mathrm{m} M$ L-glutamine (Sunshine Chemical Co. Ltd., Nanjing, China), $100 \mathrm{U} / \mathrm{mL}$ of penicillin, and $100 \mathrm{mg} / \mathrm{mL}$ of streptomycin. The cells were seeded in $25-\mathrm{cm}^{2}$ plastic tissue culture flasks (Corning Inc., Corning, NY) and incubated at $37^{\circ} \mathrm{C}$ in an incubator $\left(5 \% \mathrm{CO}_{2}\right)$ for $24 \mathrm{~h}$. Thereafter, the cells were allocated across treatments in the following manner: $\mathrm{pH} 7.4$ (control; $\mathrm{n}=8 ; 720 \mathrm{kPa}$ ) or $6.8(\mathrm{n}=8 ; 720 \mathrm{kPa})$ for $24 \mathrm{~h}$, or $20 \mathrm{~m} M$ SCFA at $\mathrm{pH} 7.4(\mathrm{n}=8 ; 820 \mathrm{kPa})$ or $6.8(\mathrm{n}=8 ; 820 \mathrm{kPa})$ for 24 h. After that, the cells were scraped off the flasks and transferred to $-80^{\circ} \mathrm{C}$ until analyzed for mRNA expression. The mixture of SCFA contained $12 \mathrm{mM}$ sodium acetate, $5 \mathrm{~m} M$ sodium propionate, and $3 \mathrm{~m} M$ sodium butyrate (Merck KGaA, Darmstadt, Germany). In the pH 6.8 group, the medium was acidified with $1 \mathrm{~N} \mathrm{HCl}$.

\section{pH and SCFA Determination}

The $\mathrm{pH}$ of rumen fluid was measured with a Mettler Toledo Delta 320 pH meter (Mettler-Toledo Group Halstead, UK) and SCFA were measured using an Agilent gas chromatograph HP6890N (Agilent Technologies Inc., New Castle, DE) as described before (Yang et al., 2012).

\section{RNA Extraction and Real-Time Quantitative PCR}

Total RNA extraction was carried out as described before (Yang et al., 2012). Complementary DNA was synthesized by using a random hexamer primer (Invitrogen, Shanghai, China) and M-MLV-reverse transcriptase according to the manufacturer's instructions (MBI Fermentas Inc., Burlington, ON, Canada). The primers for NHE1, NHE2, NHE3, vacuolar $\mathrm{H}^{+}$ATPase subunit B ( $\boldsymbol{v} \boldsymbol{H}^{+}$ATPase $)$, and MCT1 were used as described in the published literature (Etschmann et al., 2006; Graham et al., 2007; Albrecht et al., 2008). The primers for the others were designed by Primer Premier 5.0 software (Premier Biosoft International, Palo Alto, CA). The PCR products of the newly designed primers were validated by DNA sequencing. The target genes of interest and their respective sources and primer sequences are listed in Table 2. The primers were all synthesized by Shanghai Invitrogen Biological Co. (Shanghai, China).

Determination of relative mRNA expression was performed with real-time quantitative PCR by using the MyiQ2 2-color real-time quantitative PCR detection system (Bio-Rad Laboratories Inc., Hercules, CA). Real-time PCR was carried out in a total volume of 20 $\mu \mathrm{L}$ containing $1 \times \mathrm{iQ}$ SYBR Green Supermix (Bio-Rad

Table 2. Primers for real-time PCR

\begin{tabular}{|c|c|c|c|}
\hline Gene $^{1}$ & Primer sequence, $5^{\prime}$ to $3^{\prime 2}$ & Source $^{3}$ & Size (bp) \\
\hline$G A P D H$ & $\begin{array}{l}\text { TTGTCTCCTGCGACTTCA } \\
\text { CCACCACCCTGTTACTGTT }\end{array}$ & HМ043737.1 & 135 \\
\hline$D R A$ & $\begin{array}{l}\text { TTTAAAGTCCTAGAGTCCGTA } \\
\text { CGCTGATTTATTTCTTTAACCAC }\end{array}$ & BC134586.1 & 113 \\
\hline PAT1 & $\begin{array}{l}\text { CCTTGAGGCACGGCTAC } \\
\text { GCACCAGACTCCGAGACATA }\end{array}$ & BC123616.1 & 123 \\
\hline AE2 & $\begin{array}{l}\text { AGCAGCAACAACCTGGAGT } \\
\text { GGTGAAACGGGAGACGAA }\end{array}$ & NM_001205664.1 & 123 \\
\hline$M C T 1$ & $\begin{array}{l}\text { ACCAGTTTTAGGTCGTCTCA } \\
\text { GGCTTCTCAGCAACATCTACA }\end{array}$ & Somers et al. (2006) & 207 \\
\hline$M C T 4$ & $\begin{array}{l}\text { GTTTGGGATAGGCTACAGTGACACA } \\
\text { GCAGCCAAAGCGATTCACA }\end{array}$ & NM_001109980.1 & 106 \\
\hline NHE1 & $\begin{array}{l}\text { CCTCTACAGCTACATGGCCTAC } \\
\text { GGGAGATGTTGGCTTCCA }\end{array}$ & Etschmann et al. (2006) & 113 \\
\hline NHE2 & $\begin{array}{l}\text { TTGGAGAGTCCCTGCTGAAC } \\
\text { GGCCGTGATGTAGGACAAAT }\end{array}$ & Graham et al. (2007) & 257 \\
\hline NHE3 & $\begin{array}{l}\text { AGCTACGTGGCCGAGGG } \\
\text { AGACAGAGGCCTCCACGGT }\end{array}$ & Etschmann et al. (2006) & 121 \\
\hline$v H^{+}$ATPase & $\begin{array}{l}\text { TTTTATTGAACAAGAAGCCAATGA } \\
\text { GATTCATCAAATTGGACATCTGAA }\end{array}$ & Albrecht et al. (2008) & 182 \\
\hline $\mathrm{Na}^{+} / \mathrm{K}^{+}$ATPase & $\begin{array}{l}\text { TGAGCATCCCAGTGTTGT } \\
\text { CCTTGTCCAGATACTTCCT }\end{array}$ & NM_001076798.1 & 122 \\
\hline
\end{tabular}

${ }^{1} G A P D H=$ glyceraldehyde 3 phosphate dehydrogenase; $D R A=$ downregulated in adenoma; $P A T 1=$ putative anion transporter $1 ; A E 2=$ anion exchanger $2 ; M C T 1=$ monocarboxylic acid transporter $1 ; M C T 4=$ monocarboxylic acid transporter $4 ; N H E 1=\mathrm{Na}^{+} / \mathrm{H}^{+}$exchanger $1 ; N H E 2=\mathrm{Na}^{+} / \mathrm{H}^{+}$exchanger $2 ; N H E 3=\mathrm{Na}^{+} /$ $\mathrm{H}^{+}$exchanger 3; $v H^{+}$ATPase $=$vacuolar $\mathrm{H}^{+}$ATPase subunit $\mathrm{B} ; \mathrm{Na}^{+} / \mathrm{K}^{+}$ATPase $=\mathrm{Na}^{+} / \mathrm{K}^{+}$ATPase pump subunit $\alpha 1$.

${ }^{2}$ The first primer listed for each gene is the forward primer and the second primer is the reverse primer.

${ }^{3}$ The reference sequence number is given for primers whose source is the National Center for Biotechnology Information (NCBI) GenBank database (http://www.ncbi.nlm.nih.gov/genbank/). 
Laboratories Inc.), a mixture of forward and reverse primers (500 $\mathrm{n} M$ each), cDNA template $(1 \mathrm{ng})$, and sterile water for volume adjustment. An initial cycle for $30 \mathrm{~s}$ at $95^{\circ} \mathrm{C}$ was used to denature the cDNA. This was followed with 45 PCR cycles consisting of denaturation at $95^{\circ} \mathrm{C}$ for $5 \mathrm{~s}$ and primer annealing and extension at $60^{\circ} \mathrm{C}$ for $30 \mathrm{~s}$. After all PCR analyses, a melting curve analysis was carried out. All investigated PCR products showed only single melting peaks. Before the performance of PCR for experimental samples, the amplification efficiencies of all primers were calculated by using a standard dilution series. The efficiencies of all the primers used were between 97 and 101\%. All samples were analyzed in triplicate. These experiments were repeated twice with similar results. Gene expression was normalized to $G A P D H\left(\triangle \mathrm{Ct}=\mathrm{Ct}_{\text {Target }}\right.$ $-\mathrm{Ct}_{\mathrm{GAPDH}}$, where $\mathrm{Ct}=$ cycle threshold $)$. The average $\Delta \mathrm{CT}$ value of the control group (LC group in vivo experiment and $\mathrm{pH}-7.4$ group in vitro experiment) was then used as a reference value to calculate $\Delta \Delta \mathrm{Ct}$. The relative expression values were calculated by using the following formula: relative expression $=2^{-\Delta \Delta \mathrm{Ct}}$ (Livak and Schmittgen, 2001).

\section{Statistical Analyses}

All data were expressed as means \pm standard error. Differences were considered significant when $P<$ 0.05 , as tested by the independent sample $t$-test (in vivo data). The general linear model with relevant interactions was used to determine the significance of differences in mRNA abundance in vitro. All statistical analyses were performed by using SPSS (SPSS Inc., Chicago, IL) software packages.

\section{RESULTS}

\section{Ruminal Fermentation}

The goats in the MC group had lower ruminal $\mathrm{pH}$ than goats in the LC group (6.63 vs.7.03; $P=0.027$; Table 3 ). In agreement with ruminal $\mathrm{pH}$ results, total ruminal SCFA increased in the MC group compared with the LC group. Of all 6 SCFA analyzed, feeding MC increased $(P<0.05)$ the concentration of propionate by $49 \%$, butyrate by $152 \%$, and isobutyrate $45 \%$, respectively.

\section{Gene Expression In Vivo}

All of the genes evaluated in ruminal tissue were affected by the dietary treatment $(P<0.05$; Table 4$)$. Gene expression of 3 candidates for $\mathrm{SCFA}^{-} / \mathrm{HCO}_{3}{ }^{-}$exchangers, namely downregulated in adenoma $(\boldsymbol{D R} \boldsymbol{A})$,
Table 3. Effects of dietary concentrate level on ruminal short-chain FA (SCFA) and $\mathrm{pH}$ in goats $6 \mathrm{~h}$ after feeding ${ }^{1}$

\begin{tabular}{lcccc}
\hline & \multicolumn{2}{c}{ Treatment } & & \\
\cline { 2 - 3 } Item & LC & MC & SEM & $P$-value \\
\hline $\mathrm{pH}$ & 7.03 & 6.63 & 0.10 & 0.027 \\
Acetate $(\mathrm{m} M)$ & 37.3 & 46.1 & 3.41 & 0.23 \\
Propionate $(\mathrm{m} M)$ & 12.6 & 18.8 & 1.61 & 0.030 \\
Butyrate $(\mathrm{m} M)$ & 4.8 & 12.2 & 2.25 & 0.040 \\
Isobutyrate $(\mathrm{m} M)$ & 1.0 & 1.5 & 0.11 & 0.037 \\
Valerate $(\mathrm{m} M)$ & 1.0 & 1.6 & 0.15 & 0.12 \\
Isovalerate $(\mathrm{m} M)$ & 1.2 & 1.8 & 0.17 & 0.078 \\
Total SCFA $(\mathrm{m} M)$ & 58.0 & 81.9 & 6.86 & 0.037 \\
\hline
\end{tabular}

${ }^{1}$ Goats received the low-concentrate (LC) or medium-concentrate (MC) diet for at least $21 \mathrm{~d}$ before slaughter.

putative anion transporter 1 (PAT1), and anion exchanger 2 (AE2) were upregulated to a greater extent in the MC group compared with the LC group. Further, the mRNA abundances of MCT1 and MCT4, which were cotransporters of monocarboxylate anions and protons, were higher in the $\mathrm{MC}$ group than in the LC group.

The expression of genes by which the rumen epithelial cells maintain intracellular $\mathrm{pH}$, including NHE1, NHE2, and NHE3 were also evaluated by quantitative PCR. Their expressions in the MC group were enhanced relative to the LC group.

In addition, we examined the mRNA amount of 2 ATPase, which are also involved in intracellular $\mathrm{pH}$ (pHi) regulation, including $v H^{+}$ATPase and $\mathrm{Na}^{+} / \mathrm{K}^{+}$ ATPase. The expressions of $v H^{+}$ATPase and $\mathrm{Na}^{+} / \mathrm{K}^{+}$

Table 4. Effect of dietary concentrate level on the relative expression of genes related to short-chain FA absorption and intracellular $\mathrm{pH}$ regulation in ruminal epithelium of goats ${ }^{1}$

\begin{tabular}{|c|c|c|c|c|}
\hline \multirow[b]{2}{*}{ Gene $^{2}$} & \multicolumn{2}{|c|}{ Treatment } & \multirow[b]{2}{*}{ SEM } & \multirow[b]{2}{*}{$P$-value } \\
\hline & $\mathrm{LC}$ & $\mathrm{MC}$ & & \\
\hline$D R A$ & 1.14 & 3.24 & 0.44 & 0.009 \\
\hline PAT1 & 1.15 & 4.51 & 0.66 & 0.010 \\
\hline AE2 & 1.21 & 3.01 & 0.35 & 0.003 \\
\hline$M C T 1$ & 0.85 & 2.65 & 0.32 & 0.001 \\
\hline$M C T 4$ & 1.25 & 5.49 & 0.88 & 0.019 \\
\hline NHE1 & 1.06 & 2.47 & 0.30 & 0.016 \\
\hline NHE2 & 1.07 & 3.30 & 0.40 & 0.001 \\
\hline NHE3 & 1.16 & 3.50 & 0.50 & 0.017 \\
\hline$v H^{+}$ATPase & 1.20 & 6.86 & 1.06 & 0.006 \\
\hline $\mathrm{Na}^{+} / \mathrm{K}^{+}$ATPase & 1.24 & 5.86 & 0.87 & 0.006 \\
\hline
\end{tabular}

${ }^{1}$ Goats received the low-concentrate (LC) or medium-concentrate (MC) diet for at least $21 \mathrm{~d}$ before slaughter.

${ }^{2} D R A=$ downregulated in adenoma; PAT1 $=$ putative anion transporter 1; AE2 = anion exchanger 2; $M C T 1=$ monocarboxylic acid transporter $1 ; M C T 4=$ monocarboxylic acid transporter $4 ; N H E 1=$ $\mathrm{Na}^{+} / \mathrm{H}^{+}$exchanger $1 ;$ NHE2 $=\mathrm{Na}^{+} / \mathrm{H}^{+}$exchanger $2 ; N H E 3=\mathrm{Na}^{+} / \mathrm{H}^{+}$ exchanger $3 ; v H^{+}$ATPase $=$vacuolar $\mathrm{H}^{+}$ATPase subunit $\mathrm{B} ; \mathrm{Na}^{+} / \mathrm{K}^{+}$ ATPase $=\mathrm{Na}^{+} / \mathrm{K}^{+}$ATPase pump subunit $\alpha 1$. 
ATPase mRNA in the MC group were increased compared with those in the LC group.

\section{Gene Expression In Vitro}

A decrease in $\mathrm{pH}$ from 7.4 to 6.8 increased $(P<$ 0.001) MCT1 mRNA expression after $24 \mathrm{~h}$ of culture (Figure 1). Conversely, the mRNA expression of AE2 was downregulated $(P<0.001)$ by the addition of acid. The presence of SCFA $(20 \mathrm{mM})$ in the medium increased DRA, PAT1, AE2, MCT1, and $\mathrm{Na}^{+} / \mathrm{K}^{+}$ ATPase mRNA expression $(P<0.001)$. When comparing this increase at $\mathrm{pH} 7.4$ with and without SCFA, it was by $117,993,199,54$, and $67 \%$, respectively. In contrast, the expression of $v H^{+}$ATPase B subunit was decreased $(P=0.002)$ by SCFA. The expression of $D R A$ was elevated by synergistic effects of increased SCFA concentration and decreased $\mathrm{pH}$, similar to that of MCT1 (interaction: $P<0.01$; Figure 1). No interaction was observed between adding SCFA and low $\mathrm{pH}$ for mRNA expression of MCT4, PAT1, AE2, $v H^{+}$ ATPase B subunit, and $\mathrm{Na}^{+} / \mathrm{K}^{+}$ATPase (interaction: $P$ $>0.05)$. Messenger RNA expression of MCT4 was not changed by treatment.

\section{DISCUSSION}

\section{Ruminal Fermentation}

In the present study, different diets induced differences in ruminal fermentation. Ruminal total SCFA concentration was $40 \%$ greater and $\mathrm{pH}$ was $0.4 \mathrm{U}$ less in goats in the $\mathrm{MC}$ compared with the LC group when measured $6 \mathrm{~h}$ after the last feeding. This result is in agreement with previous reports that suggested that ruminal $\mathrm{pH}$ decreased and total SCFA concentrations increased as dietary concentrate-to-forage ratio (Penner et al., 2009) or NFC level (Valadares et al., 1999) increased.

\section{Effects of Diet on the Expression of Genes Related to SCFA Absorption}

Previous studies in sheep (Doreau et al., 1997) and cows (Sehested et al., 2000) revealed that feeding highly fermentable diets not only caused enhanced ruminal fermentation, but also increased SCFA absorption. Sehested et al. (2000) reported that the rumen epithelium of cows fed additional concentrate had an increased rate of butyrate transport, measured in Ussing chambers, despite unchanged absorptive surface area of the rumen papillae. One possible explanation for the observed change is that the SCFA transport system of epithelial cells was enhanced by feeding additional concentrate.
Kuzinski and Röntgen (2011) reported that the rumen epithelium of sheep fed additional concentrate had increased MCT1 expression. Similarly, a report in calves showed that the gene expression of $D R A$ was upregulated by concentrate feeding (Connor et al., 2010). These reports suggested that diets could influence the SCFA absorption capacity of rumen by regulating the transcription of transporters. In the present experiment, mRNA expression of the SCFA transporters (MCT1, MCT4, DRA, PAT1, and AE2) were all enhanced in goats in the MC compared with the LC group. These data lead to the speculation that the SCFA absorption capacity of the rumen increased when goats were fed the MC diet. Besides, the expression of genes (NHE1, NHE2, NHE3, $v H^{+}$ATPase, and $\mathrm{Na}^{+} / \mathrm{K}^{+}$ATPase) that are responsible for maintaining pHi were also upregulated to a greater extent in the MC group compared with the LC group. In agreement with our findings, Yang et al. (2012) demonstrated the mRNA expression of NHE1 and NHE3 in the rumen epithelium was greater for goats receiving additional concentrate. The results that expression of genes for SCFA transporters and intracellular $\mathrm{pH}$ regulators were both increased is of significant physiological importance, because enhanced SCFA uptake increases the intracellular proton load (Aschenbach et al., 2011), which must be excreted from the epithelial cells to maintain a constant pHi.

\section{Effects of SCFA and $\mathrm{pH}$ on the Expression of Genes Related to SCFA Absorption}

During the last decade, a surge of studies were done to determine dietary effects on the transcription changes in proteins involved in SCFA absorption (Penner et al., 2009; Kuzinski and Röntgen, 2011; Steele et al., 2011); however, most of those studies looked for individual SCFA transporter genes without further investigation into the influencing factors. The results of previous studies showed that luminal factors, especially SCFA and pH, can work as the modulators of gene transcription (DeCastro et al., 2005; Li and Li, 2006; Yang et al., 2012). Furthermore, we observed marked differences in the ruminal fermentation measurements, including SCFA concentration and ruminal $\mathrm{pH}$ in the vivo experiment. Based on the above information, we assumed that SCFA and $\mathrm{pH}$ might affect the transcription of genes related to SCFA absorption. To test the assumption, we conducted a trial in vitro.

In the present experiments in vitro, mRNA expression of DRA, PAT1, AE2, MCT1, and $\mathrm{Na}^{+} / \mathrm{K}^{+}$ATPase was stimulated by either reduced $\mathrm{pH}$ or increased SCFA concentration after $24 \mathrm{~h}$ of treatment. In accordance with our results, previous studies had shown that SCFA, especially butyrate, stimulated $D R A$ (Alrefai et 


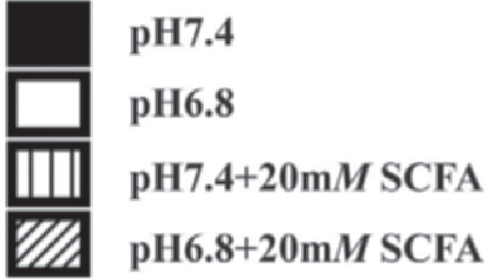

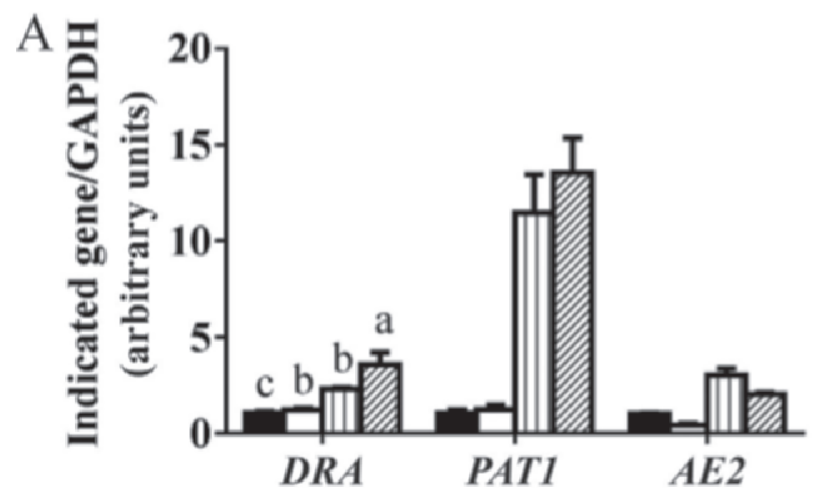

Effects on $D R A, P A T 1$, and $A E 2$ expression:

\begin{tabular}{llll} 
& DRA & PATI & AE2 \\
\hline pH & $P=0.048$ & $P=0.39$ & $P=0.001$ \\
\hline SCFA & $P<0.001$ & $P<0.001$ & $P<0.001$ \\
\hline pH*SCFA & $P=0.003$ & $P=0.47$ & $P=0.27$
\end{tabular}

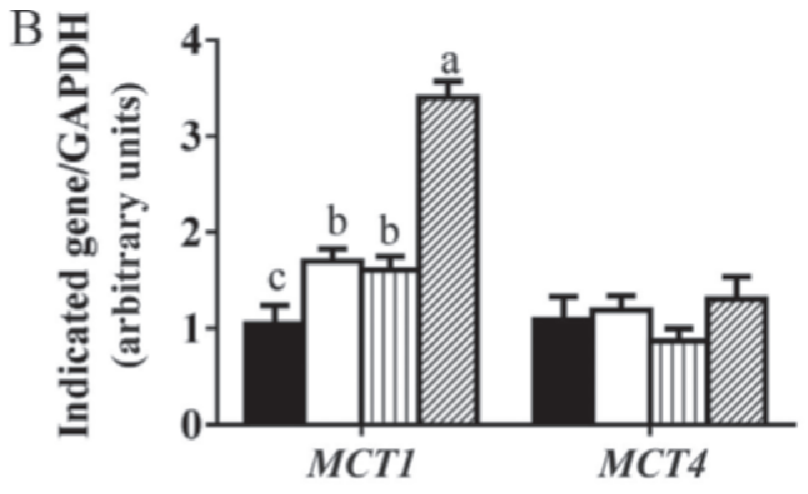

Effects on $M C T 1$ and $M C T 4$ expression:

\begin{tabular}{|lll} 
& MCT1 & MCT4 \\
\hline $\mathrm{pH}$ & $P<0.001$ & $P=0.18$ \\
\hline SCFA & $P<0.001$ & $P=0.78$ \\
\hline pH*SCFA & $P=0.003$ & $P=0.40$ \\
\hline
\end{tabular}

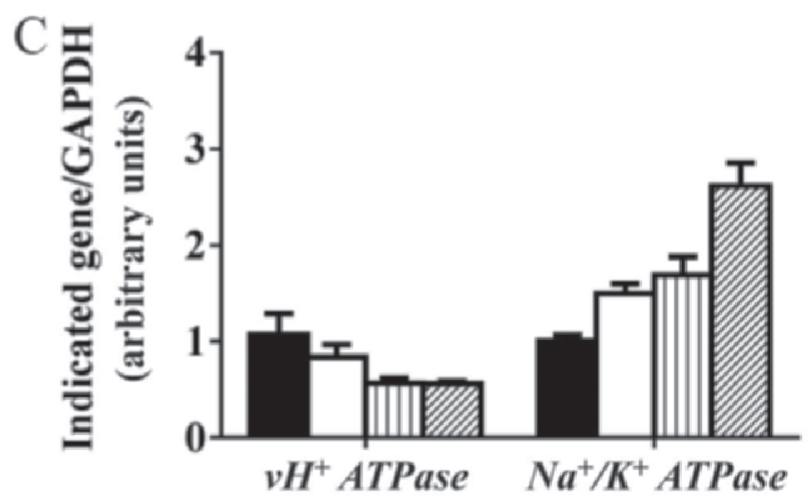

Effects on $v \mathrm{H}^{+}$ATPase and $\mathrm{Na}^{+} / \mathrm{K}^{+}$ATPase expression:

\begin{tabular}{lll} 
& $v H^{+}$ATPase & $\mathrm{Na}^{+} / \mathrm{K}^{+}$ATPase \\
\hline pH & $P=0.22$ & $P=0.001$ \\
\hline SCFA & $P=0.002$ & $P<0.001$ \\
\hline pH*SCFA & $P=0.46$ & $P=0.22$
\end{tabular}

Figure 1. In vitro effects of acid (pH 6.8), short-chain FA (SCFA; $20 \mathrm{mM}$ ), and acid (pH 6.8) + SCFA (20 mM) on gene expression in rumen epithelial cells of goats after cells were incubated for $24 \mathrm{~h}$. In groups with pH 6.8 treatment, the medium was acidified with $1 N$ HCl. The $20 \mathrm{~m} M$ SCFA contained $12 \mathrm{~m} M$ sodium acetate, $5 \mathrm{~m} M$ sodium propionate, and $3 \mathrm{~m} M$ sodium butyrate. The levels of gene expression were quantified with real-time PCR in comparison with GAPDH. Values are mean \pm SEM $(\mathrm{n}=8)$. Values within a group without a common letter $(\mathrm{a}-\mathrm{c})$ are significantly different $(P<0.05) . D R A=$ downregulated in adenoma; $P A T 1=$ putative anion transporter $1 ; A E 2=$ anion exchanger $2 ; M C T 1$ and $M C T 4=$ monocarboxylate transporters 1 and 4 , respectively; $v H^{+} A T P a s e=$ vacuolar $\mathrm{H}+\mathrm{ATPase}$ subunit $\mathrm{B} ; \mathrm{Na}^{+} / \mathrm{K}^{+} A T P a s e=\mathrm{Na}^{+} / \mathrm{K}^{+}$ ATPase pump subunit $\alpha 1$.

al., 2007) and MCT1 (Cuff et al., 2002; Borthakur et al., 2008) expression in certain types of cells (LS174T cells, AA/C1 cells, and Caco-2 cells). Our results are also in agreement with the previous observation in vivo that showed negative relationships of $\mathrm{MCT1}$ and $\mathrm{Na}^{+} /$ $K^{+}$ATPase expression in the ruminal epithelium of 
goats with decreasing luminal $\mathrm{pH}$ values, suggesting greater mRNA expression at lower $\mathrm{pH}$ (Metzler-Zebeli et al., 2013). In addition, our previous work demonstrated that low $\mathrm{pH}$ and SCFA could enhance mRNA expression of NHE1 and NHE3 after $24 \mathrm{~h}$ of incubation (Yang et al., 2012). These previous data together with the present results from the in vitro study suggest that the dietary effects on the rumen epithelial mRNA expression of those genes (DRA, PAT1, AE2, MCT1, $\mathrm{Na}^{+} / \mathrm{K}^{+}$ATPase, NHE1, and NHE3) were associated with ruminal SCFA and ruminal $\mathrm{pH}$. The effects of SCFA and $\mathrm{pH}$ on transporter expression is of significant physiological importance. Low $\mathrm{pH}$ in combination with greater SCFA concentrations imposed challenges on the SCFA absorption and pHi regulation in epithelial cells, which could be alleviated by the enhanced expression of these proteins. Our experiment also indicated a synergistic effect of low $\mathrm{pH}$ and adding SCFA on the expression of DRA and MCT1. These results further showed that reduced $\mathrm{pH}$ or increased SCFA concentration could not only act as independent factors, but when combined, they could also synergistically induce mRNA expression.

In this study, we found that the mRNA expression of AE2 was downregulated by the addition of acid. This result is in agreement with a study showing that high extracellular $\mathrm{H}^{+}$concentration led to a decrease in AE2 mRNA expression in isolated rabbit collecting duct cells (Fejes-Tóth et al., 1998). Meanwhile, we also found that both reduced $\mathrm{pH}$ and SCFA could not promote the expression of $v H^{+}$ATPase and $M C T 4$ in vitro. In addition, our previous experiments showed that neither SCFA nor $\mathrm{pH}$ affected the expression of NHE2 mRNA (Yang et al., 2012). In the present experiments, the transcription changes of these genes $\left(M C T 4, v H^{+}\right.$ATPase, and NHE2) in vivo were not aligned with the changes in vitro. One may, thus, speculate that other factors, such as hypoxia (Ullah et al., 2006) and epidermal growth factor (Xu et al., 2001), could have influenced the transcription of the latter genes. Furthermore, the effects of those factors cannot be excluded in the current vivo experiment. It is possible that the dietary treatment imposed in the current study caused different physiological and pathological changes, apart from ruminal SCFA and $\mathrm{pH}$, which affected the gene expression of MCT4, vH ATPase, and NHE2.

\section{CONCLUSIONS}

Increased dietary concentrate led to enhanced SCFA production and reduced ruminal $\mathrm{pH}$. In parallel, the expression of genes related to SCFA absorption $(D R A$, PAT1, AE2, MCT1, MCT4, NHE1, NHE2, NHE3, $\mathrm{Na}^{+} / \mathrm{K}^{+}$ATPase, and $v \mathrm{H}^{+}$ATPase) was enhanced ac- cording to the dietary concentrate. Furthermore, the results of the in vitro experiment indicated that dietary modulation of the expression of genes involved in SCFA absorption in the rumen epithelium are associated with the ruminal SCFA and ruminal $\mathrm{pH}$. The effects of SCFA and $\mathrm{pH}$ on gene transcription offer new insights into the molecular adaptation of the rumen epithelium to increased dietary concentrate.

\section{ACKNOWLEDGMENTS}

This work was supported by the Key Basic Research Program (973 Program) in China (No. 2011CB100801), the National Natural Science Foundation of China (Beijing, China; No. 30771568), and the Priority Academic Program Development of Jiangsu Higher Education Institutions (PAPD).

\section{REFERENCES}

Albrecht, E., M. Kolisek, T. Viergutz, R. Zitnan, and M. Schweigel. 2008. Molecular identification, immunolocalization, and functional activity of a vacuolar-type $\mathrm{H}^{+}$-ATPase in bovine rumen epithelium. J. Comp. Physiol. B 178:285-295.

Alrefai, W. A., X. Wen, W. Jiang, J. P. Katz, K. A. Steinbrecher, M. B. Cohen, I. R. Williams, P. K. Dudeja, and G. D. Wu. 2007. Molecular cloning and promoter analysis of downregulated in adenoma (DRA). Am. J. Physiol. Gastrointest. Liver Physiol. 293:G923-G934.

Aschenbach, J. R., G. B. Penner, F. Stumpff, and G. Gabel. 2011. Ruminant Nutrition Symposium: Role of fermentation acid absorption in the regulation of ruminal pH. J. Anim. Sci. 89:1092-1107.

Borthakur, A., S. Saksena, R. K. Gill, W. A. Alrefai, K. Ramaswamy, and P. K. Dudeja. 2008. Regulation of monocarboxylate transporter 1 (MCT1) promoter by butyrate in human intestinal epithelial cells: Involvement of NF- $\kappa$ B pathway. J. Cell. Biochem. 103:1452-1463.

Connor, E. E., R. W. Li, R. L. Baldwin VI, and C. Li. 2010. Gene expression in the digestive tissues of ruminants and their relationships with feeding and digestive processes. Animal 4:993-1007.

Cuff, M. A., D. W. Lambert, and S. P. Shirazi-Beechey. 2002. Substrate-induced regulation of the human colonic monocarboxylate transporter, MCT1. J. Physiol. 539:361-371.

DeCastro, M., B. B. Nankova, P. Shah, P. Patel, P. V. Mally, R. Mishra, and E. F. La Gamma. 2005. Short chain fatty acids regulate tyrosine hydroxylase gene expression through a cAMP-dependent signaling pathway. Brain Res. Mol. Brain Res. 142:28-38.

Doreau, M., E. Ferchal, and Y. Beckers. 1997. Effects of level of intake and of available volatile fatty acids on the absorptive capacity of sheep rumen. Small Rumin. Res. 25:99-105.

Etschmann, B., K. S. Heipertz, A. von der Schulenburg, and M. Schweigel. 2006. A vH $\mathrm{vH}^{+}$-ATPase is present in cultured sheep ruminal epithelial cells. Am. J. Physiol. Gastrointest. Liver Physiol. 291:G1171-G1179.

Fejes-Tóth, G., E. Rusvai, E. S. Cleaveland, and A. Náray-Fejes-Tóth. 1998. Regulation of AE2 mRNA expression in the cortical collecting duct by acid/base balance. Am. J. Physiol. 274:F596-F601.

Gäbel, G., M. Bestmann, and H. Martens. 1991. Influences of diet, short-chain fatty acids, lactate and chloride on bicarbonate movement across the reticulo-rumen wall of sheep. Zentralbl. Veterinärmed. A 38:523-529.

Gálfi, P., S. Neogrády, and F. Kutas. 1981. Culture of epithelial cells from bovine ruminal mucosa. Vet. Res. Commun. 4:295-300.

Graham, C., I. Gatherar, I. Haslam, M. Glanville, and N. L. Simmons. 2007. Expression and localization of monocarboxylate transporters 
and sodium/proton exchangers in bovine rumen epithelium. Am. J. Physiol. Regul. Integr. Comp. Physiol. 292:R997-R1007.

Kuzinski, J., and M. Röntgen. 2011. The mRNA and protein expression of ruminal MCT1 is increased by feeding a mixed hay/concentrate diet compared with hay ad libitum diet. Arch. Tierzucht 54:280-286.

Leonhard-Marek, S., F. Stumpff, and H. Martens. 2010. Transport of cations and anions across forestomach epithelia: Conclusions from in vitro studies. Animal 4:1037-1056.

Li, R. W., and C. Li. 2006. Butyrate induces profound changes in gene expression related to multiple signal pathways in bovine kidney epithelial cells. BMC Genomics 7:234.

Livak, K. J., and T. D. Schmittgen. 2001. Analysis of relative gene expression data using real-time quantitative $\mathrm{PCR}$ and the $2^{-\Delta \Delta \mathrm{CT}}$ method. Methods 25:402-408.

Malhi, M., H. Gui, L. Yao, J. R. Aschenbach, G. Gäbel, and Z. Shen. 2013. Increased papillae growth and enhanced short-chain fatty acid absorption in the rumen of goats are associated with transient increases in cyclin D1 expression after ruminal butyrate infusion. J. Dairy Sci. 96:7603-7616.

Metzler-Zebeli, B. U., M. Hollmann, S. Sabitzer, L. Podstatzky-Lichtenstein, D. Klein, and Q. Zebeli. 2013. Epithelial response to high grain diets involves alteration in nutrient transporter and $\mathrm{Na}^{+} /$ $\mathrm{K}^{+}$-ATPase mRNA expression in rumen and colon of goats. J. Anim. Sci. 91:4256-4266.

Penner, G. B., M. Taniguchi, L. L. Guan, K. A. Beauchemin, and M. Oba. 2009. Effect of dietary forage to concentrate ratio on volatile fatty acid absorption and the expression of genes related to volatile fatty acid absorption and metabolism in ruminal tissue. J. Dairy Sci. 92:2767-2781.
Sehested, J., J. B. Andersen, O. Aaes, N. B. Kristensen, L. Diernæs, P. D. Møller, and E. Skadhauge. 2000. Feed-induced changes in the transport of butyrate, sodium and chloride ions across the isolated bovine rumen epithelium. Acta Agric. Scand. A Anim. Sci. 50:47-55.

Somers, J., C. Smith, M. Donnison, D. N. Wells, H. Henderson, L. McLeay, and P. Pfeffer. 2006. Gene expression profiling of individual bovine nuclear transfer blastocysts. Reproduction 131:10731084 .

Steele, M. A., G. Vandervoort, O. AlZahal, S. E. Hook, J. C. Matthews, and B. W. McBride. 2011. Rumen epithelial adaptation to high-grain diets involves the coordinated regulation of genes involved in cholesterol homeostasis. Physiol. Genomics 43:308-316.

Ullah, M. S., A. J. Davies, and A. P. Halestrap. 2006. The plasma membrane lactate transporter MCT4, but not MCT1, is up-regulated by hypoxia through a HIF-1 $1 \alpha$-dependent mechanism. J. Biol. Chem. 281:9030-9037.

Valadares, R. F. D., G. A. Broderick, S. C. Valdares Filho, and M. K. Clayton. 1999. Effect of replacing alfalfa silage with high moisture corn on ruminal protein synthesis estimated from excretion of total purine derivatives. J. Dairy Sci. 82:2686-2696.

Van Soest, P. J., J. B. Robertson, and B. A. Lewis. 1991. Methods for dietary fiber, neutral detergent fiber, and nonstarch polysaccharides in relation to animal nutrition. J. Dairy Sci. 74:3583-3597.

Xu, H., J. F. Collins, L. Bai, P. R. Kiela, R. M. Lynch, and F. K. Ghishan. 2001. Epidermal growth factor regulation of rat NHE2 gene expression. Am. J. Physiol. Cell Physiol. 281:C504-C513.

Yang, W., Z. Shen, and H. Martens. 2012. An energy-rich diet enhances expression of $\mathrm{Na}^{+} / \mathrm{H}^{+}$exchanger isoform 1 and 3 messenger RNA in rumen epithelium of goat. J. Anim. Sci. 90:307-317. 